\title{
地方自治体の舗装維持管理実態を考慮した 市街地道路の効果的な路面点検手法の開発
}

\author{
富山和也 ${ }^{1} \cdot$ 川村 彰 $^{2} \cdot$ 藤田 旬 $^{3}$ ・石田 樹 $^{4}$ \\ 1正会員 博士 (工) 北見工業大学助教 工学部社会環境工学科 ( $\bar{T} 090-8507$ 北海道北見市公園町165番地) \\ E-mail : tomiyama@ mail.kitami-it.ac.jp \\ 2 正会員 博士 (工) 北見工業大学教授 工学部社会環境工学科 ( $0990-8507$ 北海道北見市公園町165番地) \\ E-mail : kawamuak@ mail.kitami-it.ac.jp \\ 3学生員 北見工業大学大学院工学研究科 社会環境工学専攻 ( 090 - 8507 北海道北見市公園町165番地) \\ E-mail : m1352200111@ std.kitami-it.ac.jp \\ 4正会員 博士 (工) (独) 土木研究所寒地土木研究所 ( T062-8602 北海道札幌市豊平区平岸1条3丁目)
}

E-mail : t-ishida@ceri.go.jp

\begin{abstract}
本研究は，地方自治体における舖装維持管理実態を整理し，その結果を基に効果的な路面点検手法につ いて検討したものである。管理実態調査の結果，地方自治体では，高頻度に道路パトロールを実施してお り，段差やポットホールなど局在する路面損傷を重視しているが，路面損傷の定量的な測定が課題となっ ていることがわかった。そこで，本研究では，加速度センサを用いた簡易路面平坦性測定装置を導入し， その測定結果にリフティングスキームに基づき設計したリフティングウェーブレットフィルタを適用する ことで，特徴的な路面損傷の検出方法を開発した。本手法は，路面情報の効率的な処理に基づき，損傷検 出を自動化できるため，市街地道路における効果的な路面点検に貢献するものと期待できる.
\end{abstract}

Key Worck surface distress, local government, pavement management system, monitoring, lifting scheme, wavelet

\section{1.はじめに}

急激な社会資本の老朽化が進む昨今，舗装マネジ メントシステム（以下，「PMS」とする）は，道路 ネットワークにおける維持・修繥の必要性や優先順 位の決定において有力なツールとなる。PMSにおい て，舖装の供用性能を定量的に把握することは極め て重要であるが11),2), 舖装供用性能のうち, 利用者 評価に直結するのは, 舗装の機能と関連したサービ ス性能であり，ラフネス (平坦性)に大きく影響され $ろ^{3)}$.

舗装の供用性能評価の概念は，1955年に米国で実 施されたAASHO道路試験に始まり4)，特にラフネス と関係した車両の乗り心地が重要視されている5 ${ }^{5}$. 今日，我が国においても，国土交通省が発表した道 路ストックの総点検実施要領 (案)において, 平坦性 の評価には乗り心地と関連したIRI (International Roughness Index: 国際ラフネス指数) が導入されてい る.

PMSを効果的に稼働させ，道路ネットワークにお ける路面状態をデータベース化し，将来的な劣化予
測をするためには，路面性状データの定量的かつ高 頻度なモニタリングが必要である。しかし，日本の 道路総延長の $90 \%$ 以上を管理する多くの地方自治体 では，管理者の目視による路面点検が主流であり， 定量的なモニタリングは行なわれていない.

一方，近年では，道路センシング技術の発達によ り，車両の振動応答に基づき平坦性の測定が可能 な，簡易型の路面モニタリングシステムが開発され ている6)-8). 特にこれらのシステムでは, RTRRMS (Response Type Road Roughness M easuring System)に 代表されるように，クォーターカー（以下，

「QC」とする）モデルを採用し，|R|の算定を指向 したものが多い.

本研究の目的は, 地方自治体に対して実施した道 路舗装の維持管理実態調査結果に基づく，(1)地方自 治体がPMSを導入するにあたっての課題の整理およ び，(2)加速度センサを用いた簡易路面平坦性測定装 置 (Mobile Profilometer: 以下, 「MPM」とする) による市街地道路の効果的な路面点検手法の開発で ある、特に，本研究では，地方自治体の路面管理実 態を考慮し，MPMを用いた特徽的な路面損傷箇所 
表-1 舖装維持管理実態調査概要

\begin{tabular}{|c|c|}
\hline 大項目 & 設問の狙い \\
\hline $\begin{array}{l}\text { 道路管理データ } \\
\text { の現状 }\end{array}$ & $\begin{array}{l}\text { 自治体が保有する道路舗装に関する情報 } \\
\text { の種類, データの保有媒体 }\end{array}$ \\
\hline $\begin{array}{l}\text { 予算制度・組織 } \\
\text { 体制 }\end{array}$ & 舗装維持管理の予算制度，予算推移，組 \\
\hline $\begin{array}{l}\text { 舗装維持管理の } \\
\text { 現状 }\end{array}$ & $\begin{array}{l}\text { 作業内容, 維持修繥判断基準，舗装劣化 } \\
\text { の重要度，苦情の状況 }\end{array}$ \\
\hline 道路管理者の意 & $\begin{array}{l}\text { 現状の維持管理手法への問題意識，改善 } \\
\text { の必要性 }\end{array}$ \\
\hline
\end{tabular}

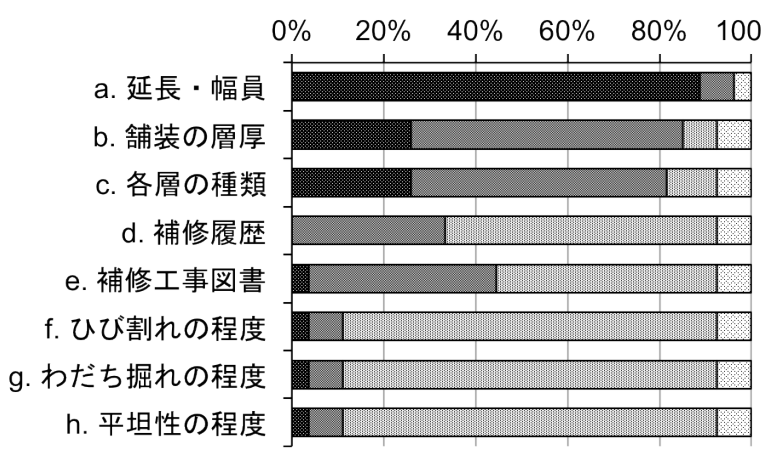

四全て保有 ロー部保有 四保有していない 林らい

図-1 道路管理データの保有状況

の特定方法について検討する.

路面損傷箇所の特定には，解析対象波形の定常性 を仮定する必要がなく，局在する損傷の位置情報と 波数（空間周波数）情報の同時識別が可能な，ウェ ーブレット変換が有望である ${ }^{9)}$. 今日, ウェーブレ ット変換は，路面の局所損傷解析への有効性が認識 されており, 路面データの分析においても多くの適 用事例が報告されている10)-12)。また，既存のウェー ブレット変換に対し，波形の特徴を学習した上で分 解および再構成が可能な，リフティングスキームが 開発されている ${ }^{13)}$. 本研究では, 加速度センサを用 いたセンシング技術に，リフティングスキームによ る情報処理を応用することで, 損傷検出を自動化し た，効率的な路面点検手法を目指寸。

\section{2. 地方自治体における舗装維持管理実態調査}

\section{（1）アンケートによる実態調査}

実態調査は，2008年に北海道内の人口 1 万人以上 （2007年当時）を有する64自治体を対象に，舗装維 持管理の現状と課題に関するアンケートおよびヒア リングにより実施した。アンケートは，WEBサイト を通じて行い，27自治体から回答が得られ，回答率 は41.5\%であった。アンケートの概要を表-1に，以 下に，各項目ごとの調查結果を示す。

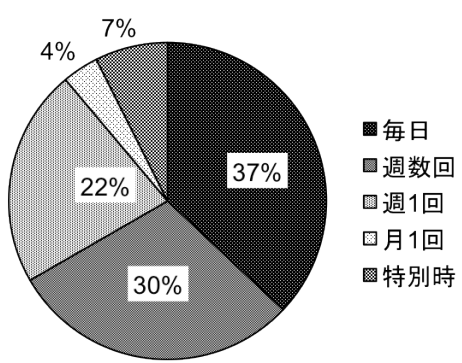

図-2＼cjkstart道路パトロール頻度

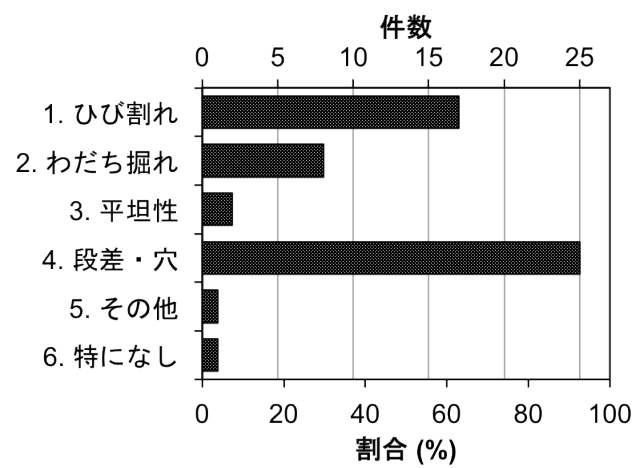

図-3 重視する路面損傷

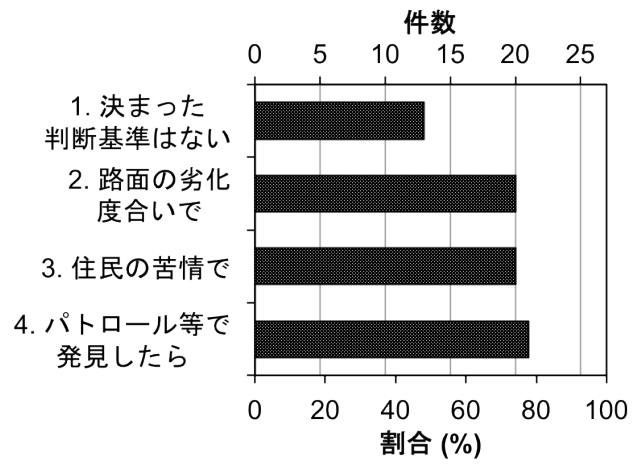

図-4 維持修繕の判断基準

\section{a）道路管理データの現状}

道路管理データの保有状況を図-1に示す。図よ り，道路関連データは，延長と幅員が主であり，路 面性状（ひび割れ，わだち掘れ，平坦性）データを 保有するのは3自治体のみであった。

\section{b）予算制度・組織体制}

道路関係予算は，1997年度から10年間で半分以下 に減少しており，道路管理予算のうち，除雪費用が 相対的に大きな割合を占めている. 技術職員数は概 永人口1万人当たり 1 人であり，管理延長 $100 \mathrm{~km}$ 当た

り1人程度の体制となる。

\section{c）舗装維持管理の現状}

図-2に道路パトロールの頻度を示す。図より，8 割以上の自治体が，緊急対応を要する箇所の把握を 目的に，週1回以上の道路パトロールを実施してい る。しかし，路面性状データ取得のための定量測定 は実施されておらず，維持修繥実施の判断は，目視 により行なわれている。なお，図-3より，最も重視 


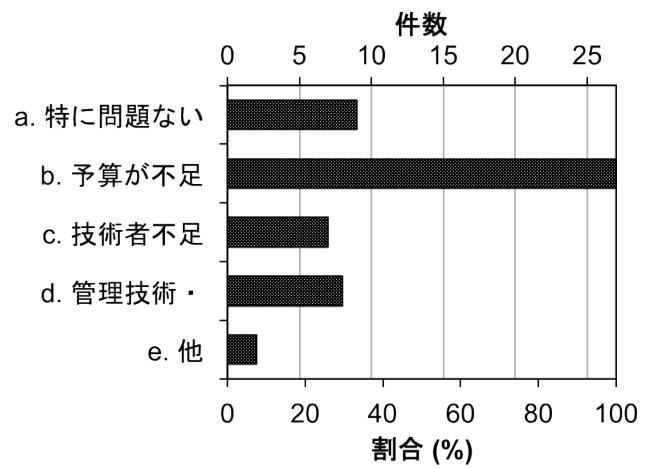

図-5 舗装維持管理上の問題点

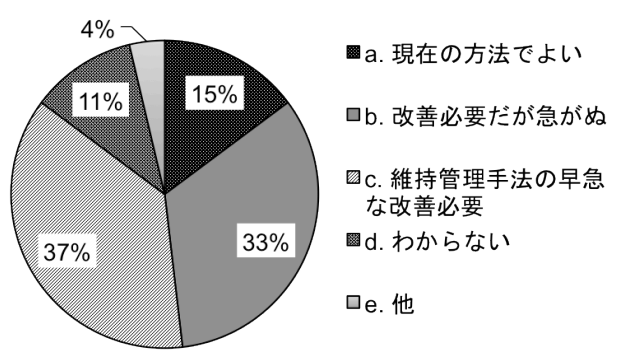

図-6 舗装維持管理に対する道路管理者意識

される舗装損傷形態は，段差およびポットホールな ど局在損傷であることがわかる。また，維持修繕 は，半数の自治体において決まった判断基準がな く，8割近くの自治体が，住民の苦情や，路面の劣 化度合に応じ，道路パトロール担当者の判断で行な っている（図-4）。

\section{d）道路管理者の意識}

図-5より予算不足が最大の懸念となっている。ま た，図-6に示寸管理者意識より，1/3強の自治体 が，対処的管理方法を早急に改善したいと考えてい る.

\section{（2）ヒアリング調査}

アンケート調查結果のうち，舗装マネジメントに 取り組んでいると回答した自治体A，および特別な 取り組みは行っておらず一般的な意識をもつ自治体 B に対しては, 舗装維持管理の道路管理担当者か ら，その実態についてヒアリングを行なった。その 結果を以下に示す.

\section{a) 自治体 $A$}

財務当局ならびに納税者に対する説明責任の観点 から, MCl（維持管理指数）で優先順位付けし, PSI（供用性指数）で補修工法を選定するシステム を考案し，5力年毎に舗装維持計画を策定してい る。路面性状調查は5年に一度，管轄路線全線を対 象に，独自に開発した評価チャートに従い，目視に より実施している。しかし，調査員の大半が事務職 員であること, ならびに目視点検の精度が課題とな っている。

\section{b）自治体B}

技術職員1名が道路管理業務全般を所掌してい る。そのため, 自治体が行なう道路パトロールの他 に，バスやタクシー等にパトロール機能の代行を依 頼している. 舖装の維持・修繥作業は, 直営による ポットホール補修が主であるが，今後5年以内に, 直営作業を行う臨時職員が半減することが懸念され ている．また，農産物を輸送する重交通によるわだ ち掘れが顕著となっているが，予算制約上，大規模 な補修が困難である。

（3）地方自治体の舗装維持管理に関する課題の整理

以上の調查結果を基に，地方自治体が抱える舗装 維持管理上の課題をPM S 観点に基づき整理すると 以下の通りである.

a) 財政的/人的制約：新たな維持管理の仕組み作り を行う余裕がない。

b）データの不備/不足：PMSの基礎となる路面性状 の定量的な情報を持っていない。

c）工学的知識/技術力の不足：問題意識はあるもの の，改善に向けた工学的かつ具体的な方法がわ からない.

d）手法の問題：既存PMSは，比較的高いクラスの 道路が対象であり，地方自治体にとって必ずし も適切ではない。

特に，厳しい財政的・人的制約下で，PMSを稼働 させるための重要な要素である, 路面性状に関する 定量的な点検手法に深刻な問題を抱えているといえ る。そこで，次章では，加速度センサを用いた MPMによる, 市街地道路の効果的な路面点検手法 について検討する.

\section{3. 簡易路面平坦性測定装置 (MPM) を用いた モニタリング原理}

地方自治体における舗装維持管理の現状調查か ら，8割以上の自治体が週1回以上の道路パトロール を実施しているが，定量的な路面点検手法が問題と なっていることが明らかとなった。本章では，従来 のレーザー変位計や水準測量による路面測定に比 心゙，経済的に導入でき効率的運用が可能な，加速度 センサを用いたM PMによる路面モニタリングにつ いて述べる。

\section{(1) MPMの概要}

本研究で用いたMPMは，任意の車両のバネ上お 


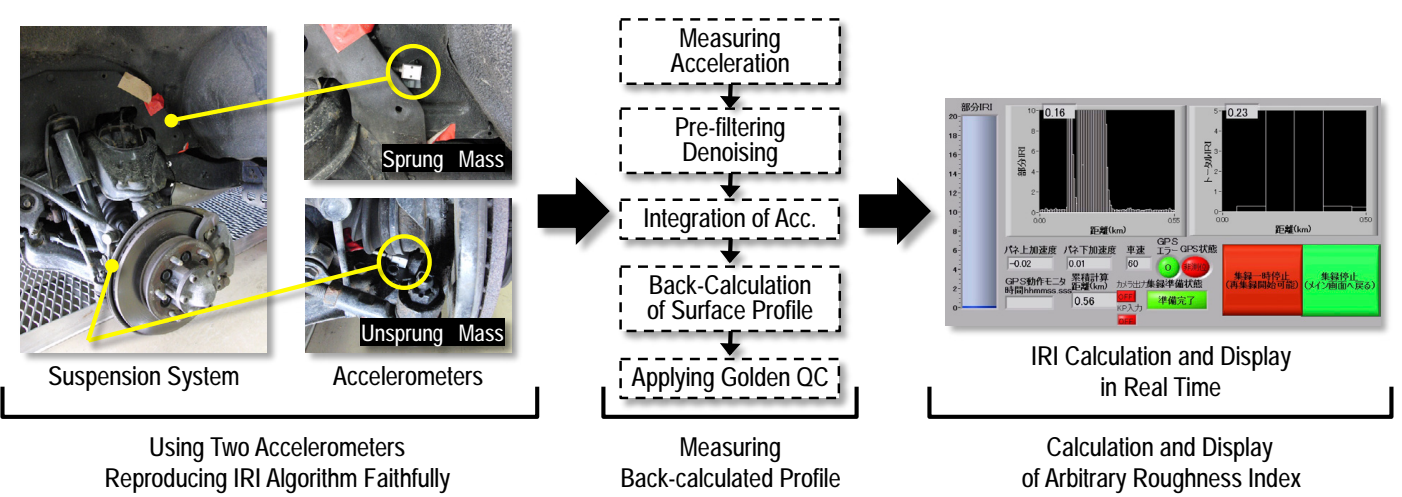

図-7 簡易路面平坦性測定装置 (M PM ) によるモニタリング原理

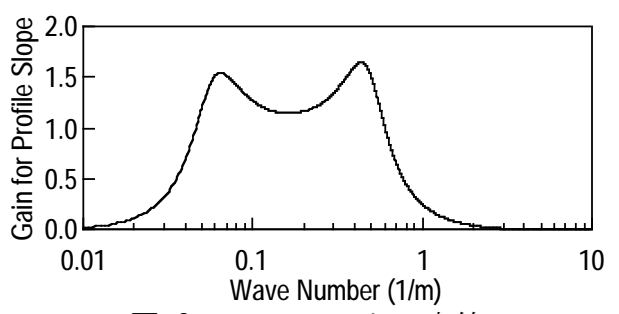

図-8 QCフィルタの応答
所要の路面損傷箇所を特定することは，路面モニタ リング上，非常に効率的である，そこで，本研究で は，MPMから得られるラフネスプロファイルに対 し，リフティングスキームを適用することで，路面 管理上重要なラフネスプロファイルの特徴を学習 し，当該箇所を特定する方法について検討する.

\section{4. リフティングスキームによる損傷検出理論}

\section{（1）ウェーブレット変換の概要}

ウェーブレット変換は, 離散および連続変換が可 能である．前者は，解析信号について，ローパスお よびハイパスフィルタとの畳み込みおよび2進間引 きにより，元信号の $1 / 2$ の解像度を持つ低周波（近 似）および高周波（詳細）成分一分解する。そのた め, 離散ウェーブレット変換では, この分解操作 を，低周波成分に繰返し行なうことで，ピラミッド アルゴリズムによる, 多重解像度解析を構成するこ とが可能である ${ }^{15)}$.

\section{（2）リフティングスキーム}

離散および連続にかかわらず，ウェーブレット変 換の結果は，マザーウェーブレットとよばれる基本 関数の性質に大きく依存寸る. そのため, 解析目的 に応じた様々な種類のマザーウェーブレットが提案 され実用化されているが，その選択は，ウェーブレ ット変換における最大の課題であった。 しかし, Second Generation Waveletsが体系化され, 既存の離 散変換に対し，リフティングスキームにより，検出 したい波形の特徴など，特定の性質を付加し，その 分解性能を高めることが可能となった ${ }^{13), 16)}$. 特に, 任意の双直交ウェーブレットフィルタに自由パラメ ータを加えた, リフティングウェーブレットフィル タ（LWF： Lifting Wavelet Filter)を用いることで，信 号に含まれる特異形状を検出する方法が提案されて 
おり ${ }^{17)}$, 路面評価への適応性も期待されている ${ }^{18)}$. リフティングスキームによる， ラフネスプロファイ ル上の特徵箇所の学習および特定方法は以下の通り である。

a）ウェーブレット分解アルゴリズム13),16),17)

距離 $l$ における信号 $c_{l}^{1}$ は, 多重解像度解析によ り，次式の通り，低周波成分と高周波成分に分解で きる。

$$
\begin{aligned}
& \hat{c}_{m}^{0}=\sum_{l} \tilde{\lambda}_{l-2 m} c_{l}^{1} \\
& \hat{d}_{m}^{0}=\sum_{l} \tilde{\mu}_{l-2 m} c_{l}^{1}
\end{aligned}
$$

$\tilde{\lambda}_{m}$ と $\tilde{\alpha}_{m}$ は分解フィルタとよばれる. また，元信号 $c_{l}^{1}$ は，低周波 $\hat{c}_{m}^{0}$ および高周波成分 $\hat{d}_{m}^{0}$ を用いて次式 により再構成可能である.

$$
c_{l}^{1}=\sum_{m} \lambda_{l-2 m} \hat{c}_{m}^{0}+\sum_{m} \propto_{l-2 m} \hat{d}_{m}^{0}
$$

ここで， $\lambda_{m}$ と $\alpha_{m}$ は再構成フィルタとよばれる，簡 単のために,

$$
\begin{array}{ll}
h_{k, l}^{\text {old }}=\lambda_{k-2 l}, & g_{m, l}^{\text {old }}=\propto_{l-2 m} \\
\tilde{h}_{k, l}^{\text {old }}=\tilde{\lambda}_{k-2 l}, & \tilde{g}_{m, l}^{\text {old }}=\tilde{\propto}_{l-2 m}
\end{array}
$$

とおくと，これらのフィルタ組 $\left\{h_{k, l}^{\text {old }}, \tilde{h}_{k, l}^{\text {old }}, g_{m, l}^{\text {old }}, \tilde{g}_{m, l}^{\text {old }}\right\}$ は $\delta$ をクロネッカーのデルタとし，双直交条件とよ ばれる以下の条件を満たすものとする.

$$
\begin{aligned}
& \sum_{l} h_{k, l}^{\text {old }} \tilde{h}_{k^{\prime}, l}^{\text {old }}=\delta_{k k^{\prime}}, \quad \sum_{l} g_{m, l}^{\text {old }} \tilde{h}_{k, l}^{\text {old }}=0 \\
& \sum_{l} h_{k, l}^{\text {old }} \tilde{g}_{m, l}^{\text {old }}=0, \quad \sum_{l} g_{m, l}^{\text {old }} \tilde{g}_{m^{\prime}, l}^{\text {old }}=\delta_{m m^{\prime}}
\end{aligned}
$$

ここで,

$\hat{c}_{m}^{0}$ : 低周波成分

$\hat{d}_{m}^{0}:$ 高周波成分

$l$ : 解像度（周波数）パラメータ

$k$ : 位置パラメータ（低周波成分）

$m$ : 位置パラメータ（高周波成分）

である。なお，上付きの数字は，解像度が一段階下 がった事をあらわすため，便宜上，入力信号を 1 , 分解信号を0とする。 また，チルダは分解側の操作 を，ハットは，分解された信号を表す.

b) LWFの設計方法 ${ }^{13), 16), 17) ~}$

LWF とは，任意の双直交ウェーブレットフィルタ に，調整可能な自由パラメータを加えたものであ り, 次式の新しい双直交ウェーブレットフィルタ組 $\left\{h_{k, l}, \tilde{h}_{k, l}, g_{m, l}, \tilde{g}_{m, l}\right\}$ で構成される.

$$
h_{k, l}=h_{k, l}^{\text {old }}+\sum_{m} \tilde{s}_{k, m} g_{m, l}^{\text {old }}
$$

$$
\begin{gathered}
\tilde{h}_{k, l}=\tilde{h}_{k, l}^{\text {old }} \\
g_{m, l}=g_{m, l}^{\text {old }} \\
\tilde{g}_{m, l}=\tilde{g}_{m, l}^{\text {old }}-\sum_{k} \tilde{s}_{k, m} \tilde{h}_{k, l}^{\text {old }}
\end{gathered}
$$

ここで， $\tilde{s}_{k, m}$ は自由パラメータであり， $\tilde{h}_{k, l}$ および $\tilde{g}_{m, l}$ は新しい低周波および高埖分解フィルタを, $h_{k, l}$ および $g_{m, l}$ は新しい低周波および高周波再構成 フィルタを表す。また，これらの新しいフィルタも 以下の双直交条件を満たす。

$$
\begin{gathered}
\sum_{l} h_{k, l} \tilde{h}_{k^{\prime}, l}=\delta_{k k^{\prime}}, \quad \sum_{l} g_{m, l} \tilde{h}_{k, l}=0 \\
\sum_{l} h_{k, l} \tilde{g}_{m, l}=0, \quad \sum_{l} g_{m, l} \tilde{g}_{m^{\prime}, l}=\delta_{m m^{\prime}}
\end{gathered}
$$

なお，オリジナルのフィルタと新しいフイルタを区 別するため，前者にoldを付記した。

\section{c）自由パラメータの学習方法 ${ }^{16)}$}

上記の式(6)をみると，信号の分解過程においてフ イルタが更新されるのは高周波側のみである。そこ で，信号の新しい高周波成分を考えると，以下のよ うになる。

$$
d_{m}^{0}=\sum_{l} \tilde{g}_{m, l} c_{l}^{1}
$$

ここに，式(6)の $\tilde{g}_{m, l}$ を代入すると，

$$
\begin{aligned}
d_{m}^{0} & =\sum_{l}\left(\tilde{g}_{m, l}^{\text {old }}-\sum_{k} \tilde{s}_{k, m} \tilde{h}_{k, l}^{\text {old }}\right) c_{l}^{1} \\
& =r_{m}-\sum_{k} a_{k} \tilde{s}_{k, m}
\end{aligned}
$$

となる。なお， $r_{m}$ と $a_{k}$ は，初期フィルタによる高 周波および低周波成分であり,

$$
r_{m}=\sum_{l} \tilde{g}_{m, l}^{\text {old }} c_{l}^{1}, \quad a_{k}=\sum_{l} \tilde{h}_{k, l}^{\text {old }} c_{l}^{1}
$$

となる．特に，高周波成分 $r_{m}$ は，信号 $c_{l}^{1}$ の不連続点 や特異箇所などの詳細な情報を与える。ここで，信 号の基本特性を知るため, 式(9)の高周波成分 $d_{m}^{0}$ を 消失させるように自由パラメータ $\tilde{s}_{k, m}$ を決定する. 高周波成分は，距離パラメータ $m$ に対応した複数の $\tilde{s}_{k, m}$ を含むことから，

$$
d_{m}^{0}=r_{m}-\sum_{k} a_{k} \tilde{s}_{k, m}=0
$$

とすることで，信号に含まれる様々な特徵を抽出す ることが可能である，以上を踏まえ，はじめに，検 出したい路面損傷形状を含む $2 n$ 個のトレーニング 信号 $(v=1,2, \ldots, 2 n)$ を用意する。トレーニング信号 は，ひび割れやパッチング，ポットホールなど，管 理目的に合わせて，検出したい路面プロファイル形 


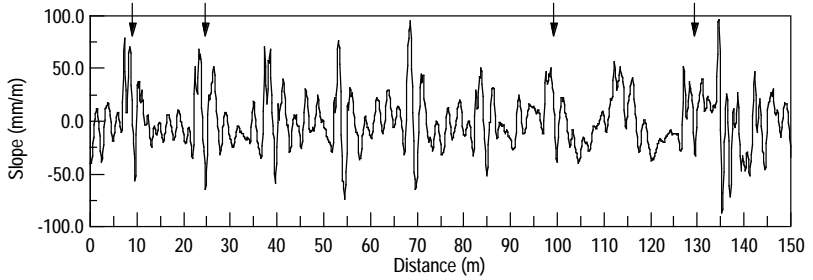

図-9 ラフネスプロファイルの測定結果

状を予め準備する，次に，各トレーニング信号に対 し，以下の条件を課す。

$$
\sum_{k=m-n}^{m+n} a_{k}^{v} \tilde{s}_{k, m}-r_{m}=0, \quad v=1,2, \ldots 2 n
$$

ここで

$$
r_{m}^{v}=\sum_{l} \tilde{g}_{m, l}^{\text {old }} c_{l}^{1, v}, \quad a_{m}^{v}=\sum_{l} \tilde{h}_{k, l}^{\text {old }} c_{l}^{1, v}
$$

である。一方，式(12)における数式が $2 n$ 個であるの に対して, 未知の $\tilde{s}_{k, m}$ が $2 n+1$ ある。しかし，フィ ルタの設計条件より $\sum_{l} \tilde{g}_{m, l}=0$ を満たす必要がある ため,

$$
\sum_{l} \tilde{g}_{m, l}=\sum_{l}\left(\tilde{g}_{m, l}^{\text {old }}-\sum_{k=m-n}^{m+n} \tilde{s}_{k, m} \tilde{h}_{k, l}^{\text {old }}\right)=0
$$

となり， $\sum_{l} \tilde{g}_{m, l}^{\text {old }}=0$ であることから, 以下の条件が 加わる.

$$
\sum_{k=m-n}^{m+n} \tilde{s}_{k, m}=0
$$

よって，式(12)，(15)より，

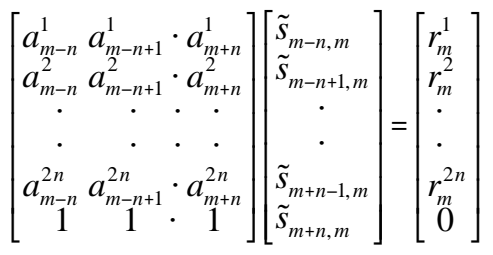

となり，この連立一次方程式を解くことで $\tilde{s}_{k, m}$ が算 出できる.

\section{d）特徵箇所の特定理論 ${ }^{16)}$}

リフティングスキームによる損傷箇所の特定は, はじめに，解析対象の信号から，新旧のハイパスウ エーブレットフィルタ $\tilde{g}_{m, l}, \tilde{g}_{m, l}^{\text {old }}$ を用いて, 高周波成 分 $d_{m}^{0}$ および $\hat{d}_{m}^{0}$ を計算する。 ここで, $\tilde{g}_{m, l}$ における 自由パラメータ $\tilde{s}_{k, m}$ が, 損傷箇所における $d_{m}^{0}$ を消失 させるよう最適化されていることに着目する，そこ で, 以下の式(17)により, 類似度 $I_{m}>0$ となる距離 $m$ により損傷箇所を特定することができる. 即ち, 表-2＼cjkstart初期ウェーブレットフィルタ

\begin{tabular}{ccccc}
\hline$k, m$ & $h_{k, l}^{\text {old }}$ & $\tilde{h}_{k, l}^{\text {old }}$ & $g_{m, l}^{\text {old }}$ & $\tilde{g}_{m, l}^{\text {old }}$ \\
\hline 0 & 0.7071 & 0.9944 & -0.9944 & -0.7071 \\
$1,-1$ & 0.3536 & 0.4198 & 0.4198 & 0.3536 \\
$2,-2$ & - & -0.1768 & 0.1768 & - \\
$3,-3$ & - & -0.0663 & -0.0663 & - \\
$4,-4$ & - & 0.0331 & -0.0331 & - \\
\hline
\end{tabular}

損傷箇所以外では, 理論上 $\hat{d}_{m}^{0}$ と $d_{m}^{0}$ が等しくなるた め $I_{m}$ が0となるが，損傷箇所において $d_{m}^{0}$ は0 (ゼロ) となるため， $I_{m}$ は $\hat{d}_{m}^{0}$ の值を保ったままとなる.

$$
I_{m}=\left|\hat{d}_{m}^{0}\right|-\left|d_{m}^{0}\right|
$$

\section{MPMを用いた市街地道路の路面点検における リフティングスキームの適用}

本章では，代表的な路面損傷である横断ひび割れ に着目し，MPMを用いた路面点検データから， LWFによる特徵箇所の検出を試みる。横断ひび割れ は，低温を原因とする場合が多く，特に寒冷地域に おいては極めて重要な損傷要因となる.

\section{（1）路面モニタリングデータ}

横断ひび割れのラフネスプロファイルデータは, 2013年3月に北海道内の市街地道路において, M PM を用いて測定した。測定結果を図-9に示す. 図中, 矢印は, 特徵点として抽出した, 後述の学習箇所で ある.なお，ラフネスプロファイルのサンプリング 間隔は0.1mである。図より，当該区間は，連続して 横断ひび割れが発生しているため, 局所的な著大波 形が頻繁に発生しているのが確認できる.

\section{（2）LWFの設計}

\section{a）初期ウェーブレットフィルタ}

従来のウェーブレット変換結果は，マザーウェー ブレットの性質に大きく依存する. リフティングス キームにおいて，LWFは，任意のウェーブレットフ イルタから構成可能であるが，本研究では，初期ウ ェーブレットフィルタとして, 再構成および分解に 用いるフィルタ長と関連するバニシングモーメント が2および4の双直交スプラインウェーブレットを用 いた。このウェーブレットフィルタは，比較的短い 次数であり, 鋭いピークを持つ基本関数で構成され るため，ひび割れのような局在する路面損傷箇所の 特定に適するものといえる. 初期ウェーブレットフ イルタ $\left\{h_{k, l}^{\text {old }}, \tilde{h}_{k, l}^{\text {old }}, g_{m, l}^{\text {old }}, \tilde{g}_{m, l}^{\text {old }}\right\}$ を表-2に示す. 


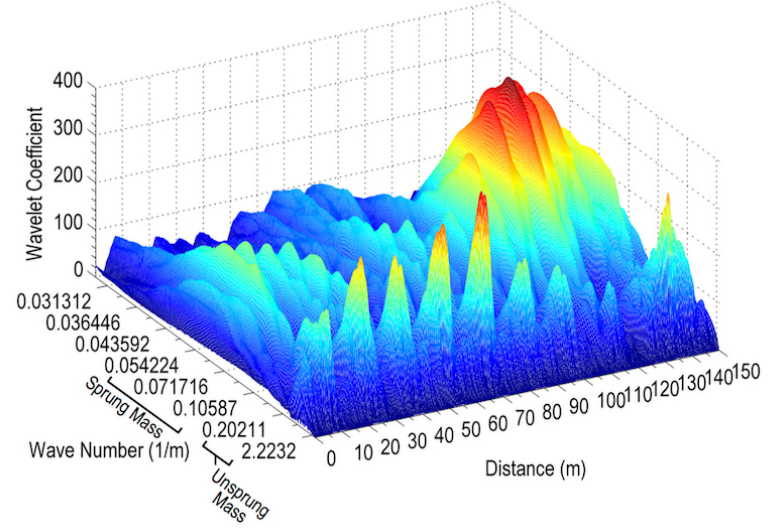

図-10＼cjkstart測定したラフネスプロファイルの 連続ウェーブレット変換結果

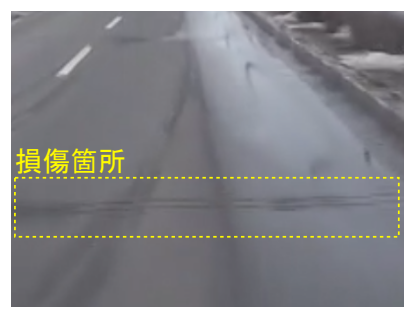

(a) トレーニング箇所

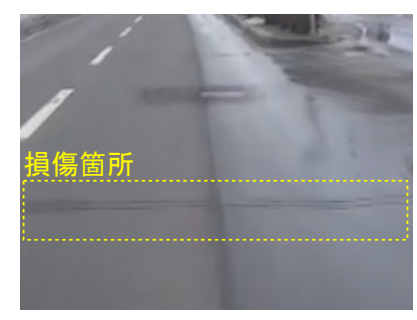

(b) 非トレーニング箇所
図-11 トレーニング箇所の損傷状況例

\section{b）トレーニング信号}

自由パラメータの学習に資するトレーニング信号 を準備するため，はじめに，連続ウェーブレット変 換による，ラフネスプロファイル測定結果の空間周 波数分析を行なった。 ウェーブレットの連続変換 は，離散変換に比べ，計算効率は劣るが，スカログ ラム (Scalogram) と呼ばれる三次元表示により， 空間周波数情報と位置情報を視覚的に把握すること ができる ${ }^{15)}$ 。ここで，位置U，スケールsにおける距 離入の関数 $f(x)$ の連続ウェーブレット変換は次式で 与えられる。

$$
W f(u, s)=\int_{-\infty}^{\infty} f(x) \frac{1}{\sqrt{s}} \psi^{*}\left(\frac{x-u}{s}\right) d x
$$

式中， *は共役複素を表す。また，ザーウェーブレ ット $\psi(x)$ は，表-2のスプラインウェーブレットで ある。

測定したラフネスプロファイルの連続ウェーブレ ット変換結果を図-10に示す。図中，市街地道路の 常用速度 $(40 \sim 60 \mathrm{~km} / \mathrm{h})$ における，一般的な乗用車の バネ上およびバネ下固有振動数と対応する波数範囲 を合わせて示した。ここで，ウェーブレット係数は 絶対值表示であり，ラフネスプロファイルの振幅ス ペクトルに相当する.

図-10より，距離10〜70m区間での，ひび割れを

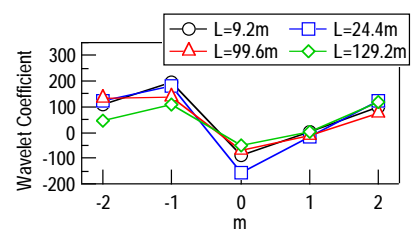

(a) 低域通過成分

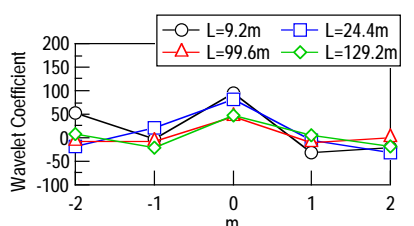

(b) 高域通過成分
図-12 トレーニング信号

表-3 自由パラメータの学習結果

\begin{tabular}{cc}
\hline$k$ & $\tilde{s}_{k, m}$ \\
\hline$m-2$ & -0.4261 \\
$m-1$ & 0.7487 \\
$m$ & -0.1172 \\
$m+1$ & -0.0281 \\
$m+2$ & -0.1772 \\
\hline
\end{tabular}

原因とする局所波形のように，一見して空間領域で は同様の傾向であっても，空間周波数平面では，特 徵が異なることがわかる。ここで，横断ひび割れの 空間周波数特性は，常用速度における，バネ下固有 振動数と対応した波長の卓越が顕著であるが，距離 10，25，100，130mでは，バネ下に加え，バネ上固有 振動数と対応した波長成分への寄与も大きく, 2つ のピークが生じている．特に，車両のバネ上振動 は，乗員の快適性に直結するため，本研究では，当 該ひび割れ4箇所をトレーニング信号とした。図-11 に，トレーニング箘所と非トレーニング箇所におけ る損傷状況の例を示寸，図より，損傷形状に大きな 違いはなく, 目視では, 空間周波数特性上の違いが 識別困難であることがわかる.

\section{c）自由パラメータの学習とフィルタの設計}

LWFは，図-9に矢印で示した損傷箇所をトレーニ ング信号に用いて自由パラメータを学習し, 初期ウ ェーブレットフィルタに付加することで設計する. 自由パラメータの学習は, 初期の離散ウェーブレッ 卜変換による多重解像度解析において，高周波（詳 細）成分が，市街地道路の常用速度における，一般 的な乗用車のバネ上およびバネ下固有振動数と対応 する路面波長（通過波数：0.625 $1.25 \mathrm{~m}(1 / \mathrm{m})$ ) を含 む, 分解レベル3から学習した。ここで, 分解レベ ル3とは，式(1)および(2)で示される操作を，3回繰 り返し行なった状態を表す. 図-12に, 自由パラメ ータの学習に用いたトレーニング信号を示す。ま た，自由パラメータの学習結果を表-3に示す. 前述 の通り，自由パラメータは，特異点における $d_{m}^{0}$ を 消失させるよう最適化されている.

ここで得られた自由パラメータ $\tilde{s}_{k, m}$ を, 式(6)に代 入することで, $\operatorname{LWF}\left\{h_{k, l}, \tilde{h}_{k, l}, g_{m, l}, \tilde{g}_{m, l}\right\}$ が設計でき る。自由パラメータを用いて更新された新しい高周 


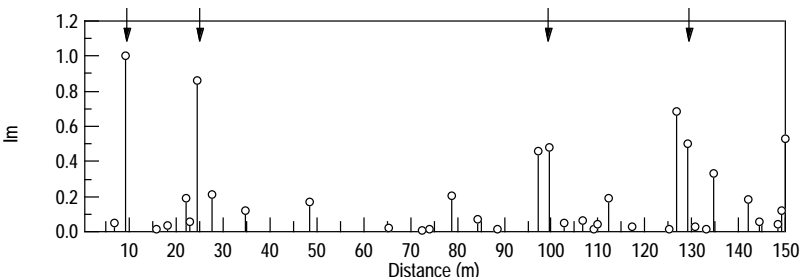

図-13 LWFによる損傷検出結果

\begin{tabular}{|c|c|c|}
\hline$k, m$ & $\begin{array}{c}\text { High Frequency } \\
\text { Decomposition } \tilde{g}_{m, l}\end{array}$ & $\begin{array}{c}\text { Low Frequency } \\
\text { Reconstruction } h_{k, l}\end{array}$ \\
\hline $\begin{array}{l}-4 \\
-3 \\
-2 \\
-1 \\
0 \\
1 \\
2 \\
3 \\
4\end{array}$ & $\begin{array}{c}0.2639 \\
0.0989 \\
0.3047 \\
-0.6287 \\
0.5287 \\
0.0725 \\
-0.0304 \\
-0.0117 \\
0.0059\end{array}$ & $\begin{array}{c}0.2639 \\
-0.0989 \\
0.3047 \\
0.6287 \\
0.5287 \\
-0.0725 \\
-0.0304 \\
0.0117 \\
0.0059\end{array}$ \\
\hline
\end{tabular}

波分解フィルタ $\tilde{g}_{m, l}$ および低周波再構成フィルタ $h_{k, l}$ を表-4に示す.

\section{（3）路面損傷箇所の特定結果}

前節までに，横断ひび割れに着目し，特徵的な路 面損傷形状に最適化したLWFを設計した。損傷箇所 は，式(17)より初期ウェーブレットフィルタおよび LWFを用いて $\hat{d}_{m}^{0}$ と $d_{m}^{0}$ を算出し, 類似度 $I_{m}>0$ とな る距離 $m$ により特定できる。ここで, 式(9)を式(17) に代入すると， $I_{m}$ は以下のように書き換えられる.

$$
I_{m}=\left|\hat{d}_{m}^{0}\right|-\left|r_{m}-\sum_{k} a_{k} \tilde{s}_{k, m}\right|
$$

上式より，実用上，損傷箇所の特定に資する類似度 $I_{m}$ の計算は，初期ウェーブレットフィルタおよび自 由パラメータを用いた計算も可能である。

図-13に，設計したLWFによる横断ひび割れの検 出結果を示す. 図中, 矢印は自由パラメータの学習 箇所である。なお，類似度 $I_{m}$ は最大值が1となるよ う正規化した。 図より, 学習したひび割れ発生箇所 が強調されており, 目視点検では困難な空間周波数 特性の違いを識別した上で，局在する路面損傷の検 出が可能であることがわかる。ここで, 特徴点検出 時の指標である $I_{m}$ の閾値については, 舗装の管理目 的に応じた設定が必要である。なお，LWFの特性 は，学習するトレーニング信号に依存するが，高頻 度に行なわれている道路パトロール時に，MPMを 用いて損傷データを蓄積し, 路面実態に合わせたフ イルタを設計することで，その性能を高めることが できる．以上から，MPMの測定結果にリフティン グスキームを適用することで，路面測定データの効
率的な情報処理，およびデータ処理結果に基づく損 傷検出の自動化により, 市街地道路における効果的 な路面点検に貢献することが期待できる.

\section{6. まとめ}

本研究では, 地方自治体における舗装維持管理実 態を整理するとともに，効果的な路面点検手法につ いて検討した。その結果，地方自治体においては， 高頻度に道路パトロールを実施しており, 段差やポ ットホール，ひび割れなど局在する路面損傷を重視 しているが，それら路面性状データの定量的な測定 が課題となっていることがわかった。 そこで, 本研 究では, 加速度センサを用いた簡易路面平坦性測定 装置 (MPM) を導入し，MPMの測定結果にリフティ ングスキームに基づき設計したリフティングウェー ブレットフィルタ (LWF)を適用した, 特徵的な路面 損傷の検出方法を開発した。また, 開発手法につい て, 市街地道路の常用速度 $(40 \sim 60 \mathrm{~km} / \mathrm{h})$ における, 一般的な乗用車のバネ上およびバネ下固有振動数と 対応する路面波長が卓越した，横断ひび割れ箇所の 特定事例を示した。その結果, 従来の目視点検では 識別困難な, 特徵的なひび割れ発生箇所が強調さ れ, 局在する路面損傷の検出が可能であることを示 した. 本成果は, 路面情報を効率的に処理し, デー 夕処理結果に基づく損傷検出を自動化できるため, 市街地道路における効果的な路面点検に貢献するも のと期待できる.

謝辞 : 舖装維持管理の実態調查は, 北海道土木技術 会の研究活動の一環として行ったものである。ま た, 市街地道路の測定には, 北海道北見市都市建設 部の協力を得た。ここに記して感謝の意を表する.

\section{参考文献}

1) 山之口浩, 丸山睡彦: 超・舗装学入門 アスファルト 舗装修繥技術 続・舗装学の寸すめ・AからZまで, 山 海堂, 1997.

2) 笠原篤: 舗装マネジメントシステム, 土木学会論文 集, No.478/N-21, pp.1-12, 1993.

3) Haas, R., and Hudson, W.R.著 北海道土木技術会舖装研 究委員会訳：最新舗装マネジメント, 北海道土木技術 会舗装研究委員会, 2000.

4) Mallick, R.B., and El-Korchi, T.: Pavement Engineering Principles and Practice, CRC Press, 2009.

5) Papet, L.M.: Federal Highway Administration - Current PMS Requirements, Pavement Management plementation, 
ASTM STP 1121, Holt, F.B. and Gramling, W.L., Eds., A merican Society of Testing and Materials, Philadelphia, pp.3-10, 1992.

6) 城本政一, 川村 彰, 坂田光児, 中島繁則：|RI測定装 置の一般道への適用に関する検討, 土木学会年次学術 講演会概要集, Vol.66, V-405, pp.809-810（CDROM ）， 2011.

7) 遠藤哲雄, 鬼倉一展, 金井利浩 : 多機能路面測定シス テムの標準化に関する検討（その2）-路面の段差量の 推定方法の考案-, 土木学会年次学術講演会概要集, Vol.66, V-407, pp.813-814 (CD-ROM) , 2011.

8) Tomiyama, K ., K awamura, A ., N akajima, S., I shida, T., and Jomoto, M.: A Mobile Data Collection System Using A ccelerometers for Pavement $M$ aintenance and Rehabilitation, Proceedings of 8th International C onference on Managing Pavement Assets, Paper No. 142 (CD-ROM), 2011.

9) 富山和也, 川村 彰, 石田 樹：クォーターカーアルゴ リズムを用いた舗装モニタリングにおける路面損傷の 検出方法，土木学会論文集F3（土木情報学），Vol. 68, No.2, pp.I_127-I_134, 2013.

10) Wei, L., and Fwa, T.F.: Characterizing Road Roughness By Wavelet Transform, Transportation Research Record, No. 1869, pp.152-158, 2004.

11) Yi, P., Sheng, L., and $Y u, L .:$ Wavelet Transform For Feature Extraction to Improve Volume A djustment Factors for Rural Roads, Transportation Research Record, No. 1879,pp. 24-29, 2004.

12) Shokouhi, P., Gucunski, N., M aher, A ., and Zaghloul, S.M .: Wavelet-Based Multiresolution Analysis of Pavement Profiles as a Diagnostic Tool, Transportation Research Record, No. 1940, pp.79-88, 2005.

13) Sweldens, W: The Lifting Scheme: A Construction of Second Generation Wavelets, SIAM Journal on Mathematical Analysis, Vol. 29, N o. 2, pp. 511-546, 1997.

14) A STM International: Standard Test M ethod for M easuring the Longitudinal Profile of Traveled Surfaces with an Accelerometer Established Inertial Profiling Reference, ASTM No.E950, 2004.

15) M allat, S. A .: Wavelet Tour of Signal Processing, A cademic Press, 1999.

16) Jansen, M., and Oonincx, P.: Second Generation Wavelets and Application, Springer, 2004.

17) Takano, T., Minamoto, H., A rimura, K., Niijima, T., Iyemori, T., and Araki, T.: Automatic detection of geomagnetic sudden commencement using lifting wavelet filters, Proceedings of the Second International Conference on D iscovery Science, pp. 242-251, 1999.

18) 川村 彰：SURF2004 と受賞論文の紹介一路面評価技術 の動向-，舗装，Vol.39，No.11，pp.24-25， 2004.

(2013.10.7 受付)

\title{
AN EFFECTIVE SURFACE INSPECTION METHOD OF URBAN ROADS ACCORDING TO THE PAVEMENT MANAGEMENT SITUATION OF LOCAL GOVERNMENTS
}

\author{
K azuya TOM IYA M A, A kira K AWA M URA, Shun FUJITA, and Tateki ISHIDA
}

This study develops an effective surface inspection method of urban roads taking the pavement management situation of local governments into consideration. A ccording to the results of questionnaire about the pavement management strategies, many local governments frequently monitor their pavement to maintain the surface condition. In the monitoring activities, they focus on localized surface deteriorations due mainly to cracks and potholes. However, the monitoring is conducted by the visual inspection rather than the quantitative measurement. A gainst this background, we introduce an accelerometer-based mobile profilometer to detect localized distresses such as transverse cracks based on the lifting scheme theory. The theory constructs lifting wavelet filters that include free parameters to enhance diagnostic surface distresses measured by the profilometer. As the result of applying the filters to the roughness profile measurement, the locations of severe distress are automatically identified. This method contributes to the pavement inspection of urban road by the automatic distress detection based on the efficient processing of surface information. 